\title{
Analisis Pemasaran Biji Kopi Robusta di Desa Jambuwer Kecamatan Kromengan Kabupaten Malang
}

Moh. Selby Hamzah a,1, Istis Baroh ${ }^{\mathrm{b}, 2,}$, , Harpowo ${ }^{\mathrm{c}, 3}$

a,b,c Program Studi Agribisnis, Fakultas Pertanian-Peternakan, Universitas Muhammadiyah Malang, Jl. Raya Tlogomas No. 246 Malang, Indonesia 1selby hamzah48@gmail.com; ${ }^{2}$ istis@umm.ac.id; ${ }^{3}$ harpowo@umm.ac.id

* corresponding author : istis@umm. ac.id

\begin{tabular}{|c|c|}
\hline ARTICLE INFO & ABSTRACT \\
\hline $\begin{array}{l}\text { Article history } \\
\text { Receiv ed: February 26, } 2021 \\
\text { Revised: March 13,2021 } \\
\text { Accepted: March 31,2021 } \\
\text { Published: March 31,2021 } \\
\text { Keywords } \\
\text { Coffee } \\
\text { Marketing } \\
\text { Marketing margin } \\
\text { Farmer's share }\end{array}$ & $\begin{array}{l}\text { Indonesia is recorded as the third largest coffee producing country in the world. } \\
\text { Robusta coffee is widely cultivated in Jambuwer Village Malang Regency. The } \\
\text { purpose of this study was to determine: Robusta coffee marketing channels in Malang } \\
\text { Regency. Calculating the amount of marketing margin, margin distribution and share } \\
\text { of robusta coffee in Malang Regency. The results of this study indicate that there are } \\
\text { four patterns of robusta coffee marketing channels, namely, marketing channel I: } \\
\text { Farmers - Wholesalers - Retailers - Consumers. Marketing channel II: Farmers - } \\
\text { Middlemen - Resellers - Consumers. Marketing channel III: Farmers - Middlemen - } \\
\text { Consumers and marketing channels IV: Farmers - Middlemen - Companies. } \\
\text { Meanwhile, the marketing margin for channel I is Rp. 4,000, marketing margin for } \\
\text { channel II is Rp. } 95,000 \text {, channel marketing margin is Rp. } 95,000 \text { and channel } \\
\text { marketing margin is Rp. 2,000. The farmer's share value in marketing channel I was } \\
84 \% \text {, marketing channel II was } 24 \% \text {, marketing channel III was } 24 \% \text { and marketing } \\
\text { channel IV was } 91.7 \% \text {. The result of the most efficient marketing channel for farmers } \\
\text { is the marketing channel IV because it has a low marketing margin and a high farmer } \\
\text { share value. } \\
\text { This is an open access article under the CC-BY-SAlicense }\end{array}$ \\
\hline
\end{tabular}

\section{PENDAHULUAN}

Sektor pertanian memiliki peran penting dalam perekonomian Indonesia. Peran sektor pertanian..tersebut dapat dilihat dari besarnya kotribusi Produk Domestik Bruto (PDB) sektor pertanian terhadap PDB nasional. Sektor pertanian juga memilikiperan penting sebagai penyedia bahan baku produksi bagi sektor industri dan juga sebagai penyedia lapangan kerja masyarakat. Pertanian di Indonesi terbagi menjadi beberapa subsektor yaitu: pangan, perkebunan, perikanan dan peternakan. Subsektor perkebunan merupakan penghasil devisa terbesar selain minyak dan gas bumi (Soetrisno, 2002).

Salah satu tanaman perkebunan yang penting di Indonesia adalah kopi. Ada empat jenis tanaman kopi yang dibudidayakan di Indonesia, yaitu Kopi Robusta, Arabika, Liberika, dan Ekselsa. Jenis tanaman kopi yang banyak diperdagangkan di Indonesia dan memiliki nilai ekonomi yang cukup tinggi yaitu Robusta dan Arabika (Rahardjo, 2013). Kualitas dari citra rasa Kopi Arabika lebih baik dari Robusta, namun budidaya tanaman kopi Arabika lebih rentan terkena penyakittanaman. Oleh karena itu, luas areal pertanaman kopi dan produksi kopi terbesar di Indonesia adalah Kopi Robusta (Sari, 2019). 
Pemasaran merupakan aspekyang sangatpenting dalam sistem agribisnis. Jika mekanisme pemasaran berjalan baik, maka semua pihak yang terlibatakan diuntungkan. (Khaswarina etal., 2019) menyatakan bahwa proses pemasaran perlu melibatkan lembaga pemasaran, oleh karena itu peran lembaga pemasaran menjadi sangat penting (Putri et al., 2018). Pemasaran juga memiliki peran penting dalam usaha pertanian. Aktivitas pemasaran merupakan tindakan ekonomi yang berpengaruh terhadap harga pasar. Tingginya produksi tidak mutlak memberikan keuntungan yang tinggi tanpa pemasaran yang baik dan efisien (Wowiling et al., 2019). Pemasaran Kopi Robusta memerlukan upaya efisiensi dan efektifitas pada saluran pemasaran, dengan tujuan untuk meningkatkan keuntungan (Pratiwi et al., 2019).

Hasil penelitian terdahulu terkait pemasaran biji kopi telah dilaksanakan oleh Caesara et al. (2017); Desiana et al. (2017); Maharani \& Furyanah (2020); Murtiningrum \& Gabrienda (2019); Pratiwi et al. (2019). Kebaharuan dari penelitian pada kondisi Pandemi Covid-19, sehingga menarik untuk dikaji terkait kondisi pemasaran beserta distribusinya dengan berbagai pemasalahan yang dihadapi seperti faktor perekonomian, kendala distribusi dan kesehatan. Selain kondisi Pandemi Covid-19, penelitian ini juga menyajikan metode indeks efisiensi saluran pemasaran sebagai ukuran efisiensi pemasaran biji kopi di Desa Jambuwer Kecamatan Kromengan Kabupaten Malang.

Desa Jambuwer merupakan salah satu penghasil Kopi Robusta di Kabupaten Malang. Ketinggian tempatnya rata-rata berada 433 meter dari permukaan laut, suhu udara berada pada kisaran $25-35^{\circ} \mathrm{C}$, sehingga sangat cocok sebagai lahan perkebunan Kopi Robusta. Petani Desa Jambuwer biasa menjual kopi dalam bentuk cerry (biji merah matang) dan greenbean (biji hijau) yang dijual melalui lembaga pemasaran hingga sampai konsumen. Lembaga Pemasaran yang berperan meliputi tengkulak, pedagang besar, pedagang pengecer, dan reseller. Adanya berbagai lembaga pemasaran serta saluran pemasaran yang berbeda menyebabkan perbedaan harga jual dan keuntungan yang diterima petani kopi di Desa Jambuwer. Semakin panjang rantai pemasaran maka semakin semakin besar margin harga. Penelitian ini bertujuan untuk menganalisis saluran pemasaran Kopi Robusta dari Desa Jambuwer, dan menganalisis efisiensi pada setiap saluran pemasaran.

\section{METODE}

Penelitian ini menggunakan metode analisis deskriptif kuantitatif. Lokasi penelitian ditentukan secara purposive (sengaja) yaitu di Desa Jambuwer Kecamatan Kromengan Kabupaten Malang. Sampel penelitian sebanyak 34 petani dari total 148 petani kopi di Desa Jambuwer. Jumlah tersebut didapatkan menggunakan rumus Slovin. Pemilihan sampel petani menggunakan metode sim ple random sam pling, sedangkan pemilihan sampel lembaga pemasaran biji kopi menggunakan metode snow ball sampling. Jumlah sampel lembaga pemasaran Kopi Robusta di Desa Jambuwer berjumlah 8 orang. Mereka terdiri terdiri dari tengkulak, pengecer, reseller dan perusahaan. Jenis data yang digunakan adalah data primer yang diperoleh melalui wawancara terstruktur dengan petani dan pedagang. Wawancara dilakukan menggunakan bantuan daftar pertanyaan (kuesioner) yang telah disiapkan. Observasi dilakukan untuk mengamati fenomena pemasaran kopi yang ada di lokasi penelitian, untuk melengkapiinformasi yang tidak tercantum dalam daftar pertanyaan.

\section{Margin Pemasaran}

Marjin pemasaran adalah selisih harga yang harus dibayarkan .oleh konsumen akhir dengan harga jual produk dari produsen/petani (Hidayatetal., 2017). Marjin pemasaran dihitung dalam satuan satuan Rupiah per Kilogram. Dua komponen utama dari marjin pemasaran adalah biaya pemasaran dan keuntungan pemasaran (Kai et al., 2016). Analisis nilai dari margin pemasaran juga dapat digunakan untuk mengetahui bagian (share) yang akan diterima oleh petani (Sofanudin \& Budiman, 2017).

Rumus margin pemasaran sebagai berikut:

\section{$\mathrm{MP}=\mathrm{Pr}-\mathrm{Pf}$}

Keterangan:

$M=$ Margin pemasaran

$\mathrm{Pr}=$ Harga kopi di tingkat.konsumen $(\mathrm{Rp} / \mathrm{Kg})$

$\mathrm{Pf}=$ Harga kopi di tingkat.produsen $(\mathrm{Rp} / \mathrm{Kg})$

\section{Distribusi Margin}

Distribusi margin merupakan pembagian komponen biaya dan keuntungan yang terjadi pada masingmasing lembaga pemasaran terlibat dalam setiap saluran pemasaran

Rumus distribusi margin sebagai berikut :

Distribusi Margin $=$ Komponen Biaya dan Keuntungan $\times 100 \%$ Margin Pemasaran (MP)

66 


\section{Farmer's Share}

Farmer's Share adalah pembagian harga yang diterima petani, yang diperoleh dengan cara membandingkan harga dari tingkat petani dan harga pada tingkat konsumen yang dinyatakan dalam bentuk persentase (Desiana et al., 2017). Semakin tinggi Farmer's share berarti semakin tinggi bagian harga yang diterima petani (Jakiyah \& Sukmaya, 2020).

Rumus Farmer's share sebagai berikut:

$$
\mathrm{Fs}=\frac{\boldsymbol{P} \boldsymbol{f}}{\boldsymbol{P r}} \times 100 \%
$$

Keterangan:

Fs $=$ Farmer's.share

$\mathrm{Pf}=$ Harga kopi di tingkat petani $(\mathrm{Rp} / \mathrm{Kg})$

$\mathrm{Pr}=$ Harga kopi di tingkat pengecer (konsumen akhir) $(\mathrm{Rp} / \mathrm{Kg})$

\section{Efisiensi Saluran Pemasaran}

Efisiensi pemasaran merupakan salah satu ukuran (indikator) pemasaran yang baik. Kegiatan pemasaran bertujuan untuk mendapatkan keuntungan yang maksimum dan tingkat efisiensi yang tinggi. Sistem pemasaran yang tidak efisien akan mengakibatkan kecilnya bagian dari harga yang diterima oleh produsen (Arafah et al., 2017).

$$
E P=\frac{\text { Biaya Pemasaran }}{\text { Nilai produk yang dipasarkan } \times 100}
$$

\section{HASIL DAN PEMBAHASAN}

Saluran pemasaran merupakan bagian dari keseluruhan jaringan penghantar nilai pelanggan. Produsen harus menyeimbangkan kebutuhan konsumen tidak hanya terhadap kelayakan dan biaya untuk memenuhi kebutuhan tetapi juga terhadap preferensi harga pelanggan (Maharani \& Furyanah, 2020). Hasil penelitian yang telah dilakukan di Desa Jambuwer, Kecamatan Kromengan, Kabupaten Malang menunjukkan ada 4 pola saluran pemasaran.

Saluran Pemasaran I: Petani $>$ Tengkulak $>$ Pengecer $>$ Konsumen

Saluran Pemasaran II: Petani $>$ Tengkulak $>$ Reseller $>$ Konsumen

Saluran Pemasaran III: Petani $>$ Tengkulak $>$ Konsumen

Saluran Pemasaran IV: Petani > Tengkulak > Perusahaan

Saluran pemasaran Kopi Robusta Desa Jambuwer terdiri dari beragam lembaga pemasaran mulai dari tengkulak, reseller, dan pengecer. Pelaku pemasaran kopi didominasi oleh tengkulak. Fenomena ini sama dengan temuan penelitian terdahulu tentang jaringan rantai pasok pemasaran kopi di Kabupaten Pasuruan yang cukup banyak agen pemasaran yang didominasi oleh tengkulak pada setiap saluran pemasaran (Aklimawati, 2018).

Setiap saluran pemasaran kopi Robusta di Desa Jambuwer memiliki segmentasi pasar yang berbeda-beda mulai dari konsumen masyarakat secara umum di pasar, cafe dan perusahaan pengekspor kopi. Adanya segmentasi pasar yang berbeda menyebabkan perbedaan perlakuan dan kualitas kopi yang dipasarkan oleh setiap lembaga pemasaran. Konsekuensinya adalah terjadi perbedaan harga yang signifikan pada beberapa lembaga pemasaran. Saluran pemasaran I memasarkan kopi pada konsumen akhir masyarakat umum. Kualitas kopi pada saluran I cenderung memiliki standar mutu rendah dan minimnya proses sortasi. Akibatnya adalah nilai jual kopi cenderung lebih rendah dibandingkan saluran pemasaran lainnya.

Sedangkan biji kopi yang dijual pada saluran pemasaran II dan III dengan segmentasi pasar Cafe memiliki kualitas kopi yang tinggi atau dikatakan sebagai kopi premium. Proses pemasaran kopi pada saluran ini melalui banyak perlakuan dan seleksi. Pemilihan bijikopi yang bagus dimulai dari seleksi biji kopi petikmerah (cherry). Selanjutnya adalah proses perambangan, bertujuan untuk memisahkan kopi yang rusak dan yang bagus. Proses penyortiran kopi juga dilakukan berdasarkan ukuran. Berbagai perlakuan tersebutmenyebabkan harga biji kopi pada saluran pemasaran II dan III lebih tinggi dibandingkan saluran pemasaran lainnya.

Biji kopi pada saluran pemasaran IV memiliki kualitas dan standar yang lebih tinggi dibandingkan dengan saluran pemasaran I. Prosesnya memiliki standar yang ditentukan oleh tengkulak, yaitu biji kopi yang dijual harus memiliki fisik luar yang baik dan juga dilakukan proses sortasi sebelum dipasarkan pada perusahan. Harga jual biji kopi pada saluran pemasaran IV lebih tinggi dibandingkan saluran pemasaran I. Temuan ini sejalan dengan (Andriadi et al., 2019) yang menyatakan bahwa di Kabupaten Aceh Tengah terdapat sistem pemasaran produk kopi yang dilakukan melalui dua cara yaitu melalui penjualan ekspor dan penjualan domestik. Ada perbedaan pendapatan petani kopi dalam untuk tujuan pemasaran yang berbeda (luar negeri 
atau dalam negeri). Petani mendapatkan keuntungan lebih pada tujuan pasar ekspor. Meskipun perbedaan kategori pasarnya tidak sama, namun esensinya adalah tujuan pemasaran yang lebih tinggi segmen pasarnya memperolehkeuntungan yang lebih tinggi. Hal ini juga sejalan dengan hasil penelitian (Higuchi et al., 2012) yang menunjukkan bahwa terdapat variasi harga kopi yang cukup besar pada berbagai saluran pemasaran.

\section{Saluran Pemasaran I}

Pada saluran pemasaran I, petani melakukan pemanenan kopi kemudian melakukan proses penjemuran kurang lebih 2 minggu kemudian petani melakukan proses pengupasan dari kulit luar kopi sebelum dijual langsung ke tengkulak dalam bentuk green been, tengkulak langsung mendatangi petani untukmembeli kopi secara tunai, yang kemudian kopi diangkut oleh Tengkulak tersebut sebelum disalurkan ke Pasar Panjen. Tengkulak melakukan pengiriman kopi kepasar Panjen dengan menggunakan mobil pick-up. Setelah tengkulak sampai di pasar, kopi kemudian dijual ke pedagang-pedangan pengecer yang sebagian besar sudah menjadi langganan dari tengkulak. Pengecer selanjutnya menjual kopi ke konsumen dengan harga lebih tinggi. Pada saluran pemasaran I ini menggunakan 2 lembaga pemasaran dan merupakan saluran pemasaran yang terpanjang

\section{Saluran Pemasaran II}

Pada saluran pemasaran II, petani melakukan pemanenan kopi dan melakukan sortasi dengan pemisahan antara kopi yg merah dan hijau. kemudian petani membawa hasil panen mengunakan motor dan pick up ketengkulak dan menjual kopi dalam bentuk basah (cherry). Tengkulak melakukan proses pengupasan dan penjemuran yang dilakukan kurang lebih 2 minggu. Setelah kering tengkulak melakukan proses pengupasan dan sortasi antara biji kopi yang bagus dan yang rusak. Setelah disortasi tengkulak melakukan roasting dan melakukan pengemasan kopi. Kopi yang sudah berbentuk rose been keemudian dikemas dan dikirim kereseller mengunakan motor. Reseller menjual kopi kekonsumen melalui sosial media dengan harga yang lebih tinggi. Pada saluran pemasaran II ini menggunakan 2 lembaga pemasaran.

\section{Saluran Pemasaran III}

Pada saluran pemasaran III, petani melakukan pemanenan kopi dan melakukan sortasi dengan

pemisahan antara kopi yg merah dan hijau. kemudian petani membawa hasil panen mengunakan motor dan pick up ketengkulak dan menjual kopi dalam bentuk basah (cherry). Tengkulak melakukan proses pengupasan dan penjemuran yang dilakukan kurang lebih 2 minggu. Setelah kering tengkulak melakukan proses pengupasan dan sortasi antara biji kopi yang bagus dan yang rusak. Setelah disortasi tengkulak melakukan roasting dan melakukan pengemasan kopi. Kopi yang sudah berbentuk rose been kemudian dikemas dan langsung dipasarkan mengunakan sosial media serta dikirim ke cafe-cafe yg sudah menjadi pelangan tetap dari tengkulak. Pada saluran pemasaran III ini menggunakan 1 lembaga pemasaran dan merupakan saluran pemasaran yang terpendek.

\section{Saluran Pemasaran IV}

Pada saluran pemasaran IV, petani melakukan pemanenan kopi kemudian melakukan proses penjemuran kurang lebih 2 minggu kemudian petani melakukan proses pengupasan dari kulit luar kopi sebelum dijual langsung ke tengkulak dalam bentuk green been, tengkulak langsung mendatangi petani untukmembeli kopi secara tunai, yang kemudian kopi diangkut oleh Tengkulak tersebut sebelum disalurkan ke PT. Asal Jaya yang ada di Dampit. Tengkulak melakukan pengiriman kopi keperusahaan dengan menggunakan mobil pickup. Pada saluran pemasaran IV ini menggunakan 1 lembaga pemasaran.

\section{Analisis Margin Pemasaran, Share dan Distribusi Margin Pada Saluran Pemasaran Kopi Robusta di Desa Jambuwer Kab. Malang}

Dua komponen utama dari Marjin pemasaran adalah biaya pemasaran dan keuntungan pemasaran . Biaya pemasaran sendiri merupakan biaya yang harus dikeluarkan dalam terjadinya proses pemasaran seperti sortasi,pengangkutan, pengemasan, bongkar muat, penyusutan, dan penyimpanan. Kecil dan besarnya marjin pada suatu saluran pemasaran dapat disebabakan dari besar kecilnya volume penjualan , jarak lokasi pemasaran dari produsen hingga konsumen akhir , fungsi fungsi pemasaran pada lembaga pemasaran, serta panjang pendeknya saluran pemasaran yang ada. (Situmorang et al., 2015) Marjin pada setiap tingkat lembaga pemasaran dapat dihitung dengan jalan menghitung selisih antara harga jual denganharga beli pada setiap tingkat lembaga pemasaran (Septiyani et al., 2017).

\section{Analisis Margin Pemasaran, Share dan Distribusi Margin Pada Saluran Pemasaran I}

Tabel 1 menunjukkan bahwa saluran pemasaran satu adalah saluran pemasaran kopi yang melalui dua rantai pemasaran yaitu tengkulak dan pengecer. rata-rata harga jual kopi dalam bentuk greenbeen di tingkat petani sebesar Rp 21.000/kg. Tengkulak A menjual kopi kepengecer dengan harga rata-rata yaitu $R p$ $22.500 / \mathrm{kg}$. Di sini tengkulak mendapatkan margin pemasaran sebesar Rp 1.500/kg dan melakukan fungsi pemasaran seperti bongkar muatRp 200/kg, dan transportasi untuk mengunakan pick up Rp 80/kg sehingga 
keuntungan yang diambil tengkulakAsebesar Rp 1220/kg. Sedangkan Pengecer menetapkan rata-rata harga jual kopi Rp 25.000/kg dan memperoleh margin pemasaran sebesar Rp 2.500/kg dan pengecer mendapatkan keuntungan sebesar Rp 2500/kg.

Tabel 1. Analisis Margin Pemasaran,Share dan. Distribusi Margin Pada Saluran Pemasaran I

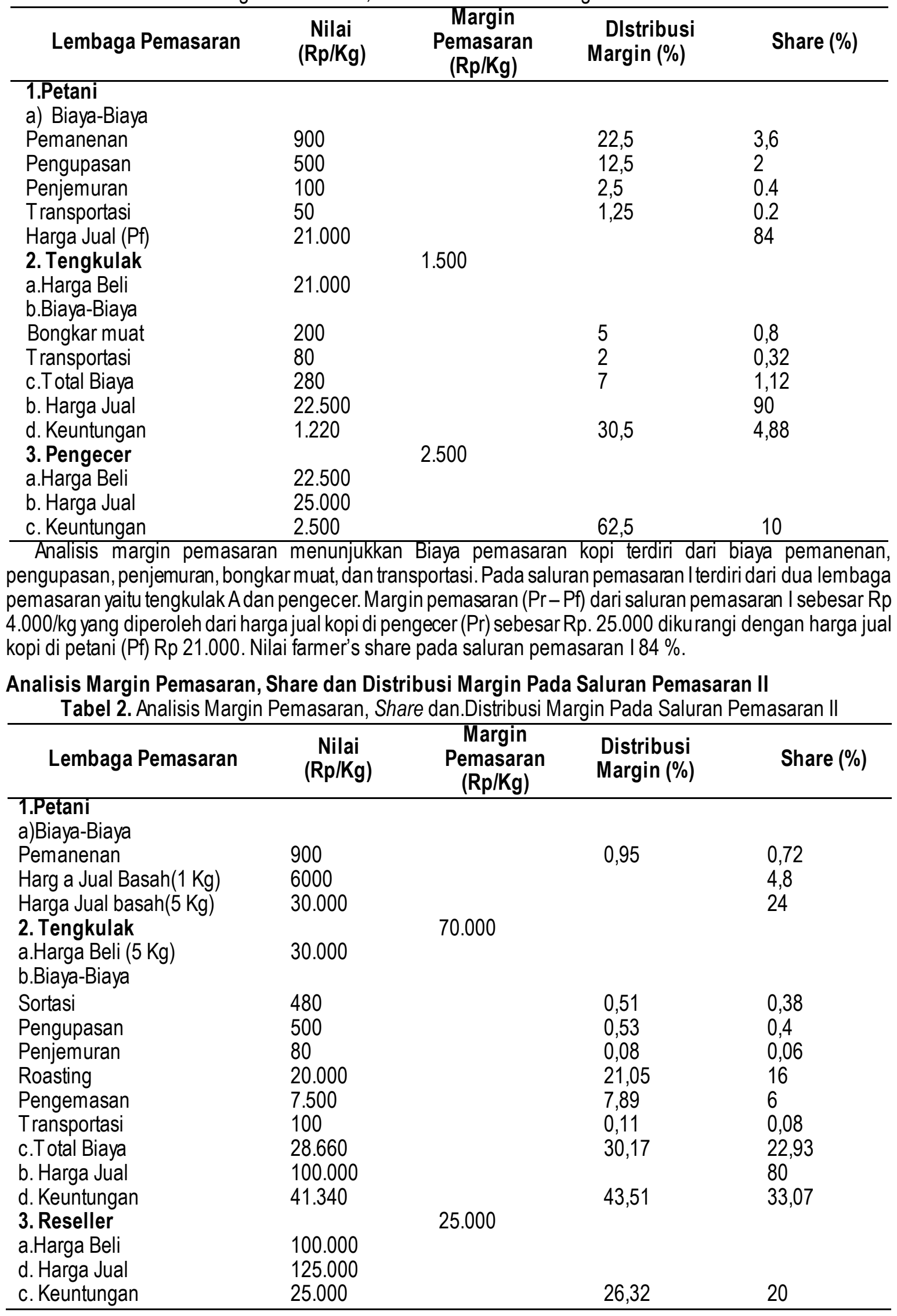


Tabel 2 menunjukkan bahwa saluran pemasaran satu adalah saluran pemasaran kopi yang melalui dua rantai pemasaran yaitu tengkulak dan pengecer. rata-rata harga jual kopi dalam bentuk greenbeen di tingkat petani sebesar Rp $21.000 / \mathrm{kg}$. Tengkulak menjual kopi kepengecer dengan harga rata-rata yaitu Rp $22.500 / \mathrm{kg}$. Di sini tengkulak mendapatkan margin pemasaran sebesar Rp 1.500/kg dan melakukan fungsi pemasaran seperti, bongkar muat Rp 200/kg, dan transportasi untuk mengunakan pick up Rp 80/kg sehingga keuntungan yang diambil tengkulak sebesar Rp 1220/kg. Sedangkan Pengecer menetapkan rata-rata harga jual kopi Rp 25.000/kg dan memperoleh margin pemasaran sebesar Rp 2.500/kg dan pengecer mendapatkan keuntungan sebesar Rp 2500/kg.

Analisis margin pemasaran menunjukkan Biaya pemasaran kopi terdiri dari biaya pemanenan, pengupasan, penjemuran, bongkar muat, dan transportasi. Pada saluran pemasaran I terdiri dari dua lembaga pemasaran yaitu tengkulak dan pengecer. Margin pemasaran ( $\mathrm{Pr}-\mathrm{Pf}$ ) dari saluran pemasaran I sebesar Rp 4.000/kg yang diperoleh dari harga jual kopi di pengecer (Pr) sebesar Rp. 25.000 dikurangi dengan harga jual kopi di petani (Pf) Rp 21.000. Nilai farmer's share pada saluran pemasaran II $24 \%$.

Analisis Margin Pemasaran, Share dan Distribusi Margin Pada Saluran Pemasaran III

Tabel 3. Analisis Margin Pemasaran, Share dan. Distribusi Margin Pada Saluran Pemasaran III

\begin{tabular}{|c|c|c|c|c|}
\hline Lembaga Pemasaran & $\begin{array}{c}\text { Nilai } \\
(\mathrm{Rp} / \mathrm{Kg})\end{array}$ & $\begin{array}{l}\text { Margin } \\
\text { Pemasaran } \\
(\mathrm{Rp} / \mathrm{Kg})\end{array}$ & $\begin{array}{l}\text { Distribusi } \\
\text { Margin (\%) }\end{array}$ & Share (\%) \\
\hline \multicolumn{5}{|l|}{$\begin{array}{l}\text { 1.Petani } \\
\text { a)Biaya-Biaya }\end{array}$} \\
\hline Pemanenan & 900 & & 0,95 & 0,72 \\
\hline Harga Jual Basah $(1 \mathrm{Kg})$ & 6000 & & & 4,8 \\
\hline Harga Jual basah $(5 \mathrm{Kg})$ & 30.000 & & & 24 \\
\hline $\begin{array}{l}\text { 2. Tengkulak } \\
\text { a.Harga Beli }(5 \mathrm{Kg}) \\
\text { b.Biava-Biava }\end{array}$ & 30.000 & 95.000 & & \\
\hline Sortasi & 480 & & 0,51 & 0,38 \\
\hline Penqupasan & 500 & & 0,53 & 0,4 \\
\hline Penjemuran & 80 & & 0,08 & 0,06 \\
\hline Roasting & 20.000 & & 21,05 & 16 \\
\hline Pengemasan & 7.500 & & 7,89 & 6 \\
\hline Transportasi & 100 & & 0,11 & 0,08 \\
\hline c.T otal Biaya & 28.660 & & 30,17 & 22,93 \\
\hline b. Harga Jual & 125.000 & & & \\
\hline d. Keuntungan & 66.340 & & 69,83 & 53,07 \\
\hline
\end{tabular}

Tabel3 menunjukkan bahwa saluran pemasaran dua adalah saluran pemasaran kopi yang melalui dua rantai pemasaran yaitu tengkulak dan reseller. Pada saluran pemasaran ini petani menjual kopi dalam bentuk cherrydengan rata-rata harga jual sebesar Rp $6.000 / \mathrm{kg}$. Tengkulak B membutuhkan $5 \mathrm{~kg}$ kopi dalam bentuk cherryuntuk dijadikan $1 \mathrm{~kg}$ kopi dalam bentuk rose bean yang didapatkan dengan harga Rp.30.00015kg dan tengkulak menjual kopi dalam bentuk rose been dengan harga rata- rata yaitu Rp 100.000/kg. Di sini tengkulak mendapatkan margin pemasaranyang cukup besar yaitu Rp 70.000/kg karena tengkulak menjual kopinya dalam bentuk Rosebeen dan melakukan fungsi pemasaran seperti, sortasi Rp 480/kg, pengupasan Rp500/kg, penjemuran Rp 80/kg, Roasting Rp20.000/kg, pengemasan Rp 7.500/kg dan transportasi Rp $100 / \mathrm{kg}$ sedangkan keuntungan yang diambil tengkulak sebesar Rp 41.340/kg. Sedangkan Pengecer menetapkan rata-rata harga jual kopi Rp 125.000/kg dan memperoleh margin pemasaran sebesar Rp $25.000 / \mathrm{kg}$ dan pengecer mendapatkan keuntungan sebesar Rp 25.000/kg .

Analisis margin pemasaran menunjukkan Biaya pemasaran kopi terdiri dari biaya pemanenan, sortasi, pengupasan, penjemuran, roasting,pengemasan dan transportasi. Pada saluran pemasaran III terdiri dari dua lembaga pemasaran yaitu tengkulak dan Reseller. Margin pemasaran ( $\mathrm{Pr}-\mathrm{Pf})$ dari saluran pemasaran II Isebesar Rp 95.000/kg yang diperoleh dari harga jual kopi di Reseller ( $\operatorname{Pr}$ ) sebesar Rp.125.000 dikurangi dengan harga jual kopi di petani $5 \mathrm{~kg}$ (Pf) Rp 30.000. Nilai farmer's share pada saluran pemasaran III $24 \%$. 
Analisis Margin Pemasaran, Share dan Distribusi Margin Pada Saluran Pemasaran IV

Tabel 4. Analisis Margin Pemasaran, Share dan. Distribusi Margin Pada Saluran Pemasaran IV

\begin{tabular}{|c|c|c|c|c|}
\hline Lembaga Pemasaran & $\begin{array}{c}\text { Nilai } \\
(\mathrm{Rp} / \mathrm{Kg})\end{array}$ & $\begin{array}{l}\text { Margin } \\
\text { Pemasaran } \\
\text { (Rp/Kg) }\end{array}$ & $\begin{array}{l}\text { Distribusi } \\
\text { Margin (\%) }\end{array}$ & Share (\%) \\
\hline \multicolumn{5}{|l|}{$\begin{array}{l}\text { 1.Petani } \\
\text { a)Biaya-Biaya }\end{array}$} \\
\hline Pemanenan & 900 & & 45 & 3,75 \\
\hline Pengupasan & 500 & & 25 & 2,08 \\
\hline Penjemuran & 100 & & 5 & 0,42 \\
\hline Transportasi & 50 & & 2,5 & 0,21 \\
\hline Harga Jual (Pf) & 22.000 & & & 91,7 \\
\hline 2. Tengkulak C & & 2000 & & \\
\hline $\begin{array}{l}\text { a.Harga Beli } \\
\text { b.Biaya-Biaya }\end{array}$ & 22.000 & & & \\
\hline Bongkar muat & 100 & & 10 & 0,84 \\
\hline Transportasi & 166 & & 8,3 & 0,69 \\
\hline c.Total Biaya & 266 & & 18,3 & 1,52 \\
\hline b. Harga Jual & 24.000 & & & \\
\hline d. Keuntungan & 1.644 & & 82,2 & 6,85 \\
\hline
\end{tabular}

Tabel 4 menunjukkan bahwasaluran pemasaran empatadalah saluran pemasaran kopi yang melalui satu rantai pemasaran yaitu tengkulak. Rata-rata harga jual kopi dalam bentuk greenbeen di tingkat petani sebesar Rp 22.000/kg. Tengkulak menjual kopi dengan harga rata-rata yaitu Rp 24.000/kg. Di sini tengkulak mendapatkanmargin pemasaran sebesar Rp 2.000/kg dengan cara menjual kopi dalam bentuk greenbeen langsung kekonsumenindustri. tengkulak melakukan fungsi pemasaran seperti, bongkar muat Rp 100/kg, dan transportasi Rp 166/kg dalam mengunakan kendaraan pick up untuk mengirim Kopi Robusta kekonsumen industri sedangkan keuntungan yang diambil tengkulak sebesar Rp 1644/kg.

Analisis margin pemasaran menunjukkan Biaya pemasaran kopi terdiri dari biaya pemanenan, pengupasan, penjemuran, bongkar muat, dan transportasi. Pada saluran pemasaran IV terdiri dari satu lembaga pemasaran yaitu tengkulak. Margin pemasaran $(\mathrm{Pr}-\mathrm{Pf})$ dari saluran pemasaran IV sebesar $\mathrm{Rp}$ $2.000 / \mathrm{kg}$ yang diperoleh dari harga jual kopi di tengkulak (Pr) sebesar Rp. 24.000 dikurangi dengan harga jual kopi di petani (Pf) Rp 22.000. Nilai farmer's share pada saluran pemasaran IV 91,7\%. Sehingga bila ditinjau dari nilai margin pemasaran dan Farmer's share saluran pemasaran IV adalah saluran pemasaran yang paling efisien, saluran pemasaran IV juga merupakan saluran pemasaran yang tersingkat dengan melibatkan 1 lembaga pemasaran hal ini sejalan dengan penelitian (Caesaraetal., 2017) yang meneliti tentang pemasaran biji kopi arabika di Kabupaten Bener dengan hasil bahwa semakin banyak lembaga pemasaran yang terlibat dalam saluran pemasaran maka semakin besar pula margin pemasaran yang dihasilakan dan semakin tidak efektif saluran pemasaran tersebut.

\section{Analisis Efisiensi Pemasaran Kopi Robusta di Desa Jambuwer Kabupaten Malang}

Analisis ini digunakan untuk mengetahuiapakah harga pasar mampu menggambarkan biaya pemasaran pada saluran pemasaran kopi yang meliputi biaya transportasi dan biaya processing.

1. Efisiensi Harga Berdasarkan Biaya Transportasi

Efisiensi harga dari biaya transportasi adalah dengan menghitung jumlah harga pembelian kopi dan biaya transpotasi, dimana harus lebih kecil dari harga jual kopi. Dapatjuga dianalisis dengan menghitung selisih antara harga jual dengan harga beli kopi pada lembaga pemasaran, dimana harus lebih besar dari biaya transportasi. Berikut ini perhitungan efsiensi harga menurut fungsi transportasi

Berdasarkan Tabel 5 dapat dilihat bahwa Fungsi pemasaran transportasi dilakukan oleh lembaga pemasaran yaitu tengkulak. Pada biaya tran sportasi tengkulak biaya ditangung oleh tengkulak secara langsung. Sedangkan untuk biaya transportasi dari reseller dan pengecer dibebankan pada konsumen. lembaga pemasaran melakukan fungsi transportasi bertujuan untuk menyalurkan kopi dari petani ke lembaga pemasaran. Dari hasil diatas dapat diketahui bahwa selisih harga kopi $(\mathrm{Rp} / \mathrm{Kg})$ lebih besar dengan rata-rata biaya transportasi lembaga pe masaran pada tiap saluran pemasaran. Jadi dapat dikatakan bahwa fungsi transportasi yang dilakukan setiap lembaga pemasaran sudah sangat efisien. Hal tersebut sejalan dengan penelitian dari (Jakiyah \& Sukmaya, 2020) yang dilakukan di Kabupaten Tasikmalaya pada lembaga pemasaran manggis dikatakan sudah efisien, karena rata-rata biaya yang dikeluarkan masih relatif lebih kecil dibandingkan dengan selisih harga. 
Tabel 5. Tingkat Efisiensi Harga Berdasarkan Fungsi Transportasi Pada Lembaga Pemasaran

\begin{tabular}{cccc}
\hline $\begin{array}{c}\text { Saluran } \\
\text { Pemasaran }\end{array}$ & $\begin{array}{c}\text { Lembaga } \\
\text { Pemasaran }\end{array}$ & $\begin{array}{c}\text { Selisin Harga } \\
\mathbf{( R p / K g )}\end{array}$ & $\begin{array}{c}\text { Rata-Rata Biaya } \\
\text { Transportasi (Rp/Kg) }\end{array}$ \\
\hline I & Tengkulak & 1.500 & 80 \\
& Pengecer & 2.500 & 0 \\
II & Tengkulak & 70.000 & 100 \\
III & Reseller & 25.000 & 0 \\
IV & Tengkulak & 95.000 & 100 \\
& Tengkulak & 2000 & 166
\end{tabular}

2. Efisiensi Harga Berdasarkan Biaya Processing

Efisiensi harga menurut biaya processing merupakan jumlah antara harga beli dari kopi dan biaya processing yg dilakukan harus lebih kecil dari harga jual kopi. Selain itu juga dapat dianalisis melal ui selisih antara harga jual dan harga beli kopi pada lembaga pemasaran, dimanaharus lebih besar dari biaya processin

Tabel 6. Tingkat Efisiensi Harga Berdasarkan Fungsi processing Pada Lembaga Pemasaran

\begin{tabular}{cccc}
\hline Saluran Pemasaran & $\begin{array}{c}\text { Lembaga } \\
\text { Pemasaran }\end{array}$ & Selisih Harga (Rp/Kg) & $\begin{array}{c}\text { Rata-Rata Biaya } \\
\text { Transportasi (Rp/Kg) }\end{array}$ \\
\hline I & Tengkulak & 1.500 & 280 \\
& Pengecer & 2.500 & 0 \\
II & Tengkulak & 70.000 & 28.660 \\
III & Reseller & 25.000 & 0 \\
IV & Tengkulak & 95.000 & 28.660 \\
\hline
\end{tabular}

Berdasarkan T abel 6 dapat dilihatbahwa Fungsi processing dilakukan oleh lembagapemasaran tengkulak. Tengkulak melakukan processing berupa bongkar muat, sortasi, penjemuran,pemisahan kulit kopi, peroastingan dan pengemasan. Sedangkan untukpengecer dan reseller tidak mengeluarkan biaya processing kerena pengecer dan reseller langsung menjual kopi kekonsumen tampa melakukan proses pengolahan.. Dari hasil diatas dapat diketahui bahwa selisih harga kopi $(\mathrm{Rp} / \mathrm{Kg})$ lebih besar dengan rata-rata biaya processing lembaga pemasaran pada tiap saluran pemasaran. Jadi dapat dikatakan bahwa fungsi processing yang dilakukan setiap lembagapemasaran sudah sangat efisien. Hal tersebutsejalan dengan penelitian(Puspasari et al., 2017) yang meneliti tentang bunga mawar potong di Desa Gunungsari berdasarkan pendekatan fungsi processing pada lembaga pemasaran bunga mawar potong di Desa Gunungsari dikatakan sudah efisien, karena rata-rata biaya yang dikeluarkan masih relatif lebih kecil dibandingkan dengan selisih harga yang didapat oleh masing-masing lembaga pemasaran bunga mawar potong.

Tabel 7. Perhitungan Nilai Indeks Efisiensi Pada Saluran Pemasaran Kopi Robustadi Desa Jambuwer Kabupaten Malang

\begin{tabular}{clllll}
\hline \multirow{2}{*}{ No } & \multicolumn{1}{c}{ Keterangan } & \multicolumn{3}{c}{ Saluran Pemasaaran } & \multicolumn{1}{c}{ PV } \\
& \multicolumn{1}{c}{ I } & \multicolumn{1}{c}{ II } & \multicolumn{1}{c}{ III } & \multicolumn{1}{c}{ IV } \\
\hline 1 & Harga JualTingkatKonsumen $(\mathrm{V})$ & 24.000 & 125.000 & 125.000 & 25.000 \\
2 & Total Biaya Pemasaran (I) & 280 & 28.660 & 28.660 & 266 \\
3 & Indeks Efisiensi Saluran & 84,71 & 3,36 & 3,36 & 92,98
\end{tabular}

Pemasaran (ME)

Dari Tabel7 di atas dapat diketahui nilai indeks efisiensi padasaluran pemasaran I sebesar 84.71, indeks efisiensi saluran pemasaran II sebesar 3,36, indeks efisiensi saluran pemasaran III sebesar 3,36 dan indeks efisiensi saluran pemasaran IV sebesar 92,98. Semakim tingginilai efisiensi pemasaran kopi di setiap saluran pemasaran, maka semakin tinggi efisiensi pada saluran tersebut. Sehingga dapat disimpulkan bahwa saluran pemasaran IV adalah saluran pemasaran yang paling efisien dengan harga jual rata-rata $R p 25.000 \mathrm{~kg}$ dan total biaya pemasaran Rp 266/kg, sedangkan nilai efisiensi yang terendah berada pada saluran pemasaran II dan III dengan harga jual rata-rata Rp $125.000 / \mathrm{kg}$ dan total biaya pemasaran Rp 28.660/kg. Sehingga dapat dikatan bahwa keutungan terbesar berada pada saluran pemasaran IV dengan konsumen akhir perusahaan. Hal ini sejalan dengan penelitian yang dilakukan (Murtiningrum \& Gabrienda, 2019) di lakukan Kabupaten Rejang Lebong Petani Yang diterima petani, terbesar diperoleh jika petani menjual kopinya ke industri pengolahan kopi yaitu sebesar $98,65 \%$. 


\section{KESIMPULAN}

Terdapatempat saluran pemasaranBiji Kopi Robusta Desa Jambuwer Kecamatan Kromengan Kabupaten. Dengan Nilai margin pemasaran saluran pemasaran I sebesar Rp 4.000 , margin pemasaran saluran II sebesar Rp 95.000, margin pemasaran saluran III sebesar Rp 95.000 dan margin pemasaran saluran IV sebesar Rp 2.000. Hal ini menunjukkan bahwa saluran pemasaran IV lebih efisien, karena margin pemasaran yang lebih kecil dari saluran pemasaran lainya dan jumlah lembaga pemasaran yang terlibat lebih sedikit. Nilai farmer's share pada saluran pemasaran I sebesar 84\%, pada saluran pemasaran II 24\%, pada saluran pemasaran III $24 \%$ dan saluran pemasaran IV sebesar $91,7 \%$. Sehingga dapat disimpulkan bahwa saluran pemasaran IV adalah saluran pemasaran dengan nilai tertinggi. Berdasarkan Indeks Efisiensi Pemasaran menunjukkan indeks efisiensi saluran pemasaran I sebesar 84,71 , indeks efisiensi saluran pemasaran II sebesar 3,36, indeks efisiensi saluran pemasaran Illsebesar 3,36 dan, indeks efisiensi saluran pemasaran IV sebesar 92,98. Semakin besar indeks efisiensi pemasaran, maka akan semakin efisien. Sehingga dapat disimpulkan bahwa saluran pemasaran IV adalah saluran pemasaran yang paling efisien.

\section{DAFTAR PUSTAKA}

Aklimawati, L. (2018). Study on Coffee Marketing and Farmer Organization in Pasuruan District. Pelita Perkebunan (a Coffee and Cocoa Research Journal), 34(2), 113-127. https://doi.org/10.22302/iccri.jur.pelitaperkebunan.V34i2.320

Andriadi, A, Ismail, R., Fikarwin, F., Badaruddin, B., Manurung, R., \& Sitorus, H. (2019). Coffee Marketing Mechanism: Social Relations Between Farmers, Collectors, Certification Cooperatives, and Exporters in Aceh, Indonesia. Pelita Perkebunan (a Coffee and Cocoa Research Journal), 35(2), 156-166. https://doi.org/10.22302/iccri.jur.pelitaperkebunan.V35i2.383

Arafah, N., Iskandar, E., \& Fauzi, T. (2017). Analisis Pemasaran Bawang Merah (Allium cepa) di Desa Lam manyang Kecamatan Peukan Bada Kabupaten Aceh Besar. Jurnal IImiah Mahasiswa Pertanian, 2(1), 134140. https://doi.org/10.17969/jimfp.V2i1.2259

Caesara, V., Usman, M., \& Baihaqi, A. (2017). Analisis Pendapatan dan Efisiensi Pemasaran Biji Kopi (Green Bean) Arabika di Kabupaten Bener Meriah. Jurnal IImiah Mahasiswa Pertanian, 2(1), 250-261. https://doi.org/10.17969/jimfp.V2i1.2306

Desiana, C., Rochdiani, dini, \& Pardani, C. (2017). Analisis Saluran Pemasaran Biji Kopi Robusta (Suatu Kasus Di Desa Kalijaya Kecamatan Banjarsari Kabupaten Ciamis). https://jurnal.unigal.ac.id/index.php/agroinfogaluh/article/view/710/614

Hidayat, R. S., Rusman, Y., \& Ramdan, M. (2017). Analisis Saluran Pemasaran Gula Aren (Arenga Pinnata) (Studi Kasus Di Desa Capar Kecamatan Salem Kabupaten Brebes). JURNAL ILMIAH MAHASISWA AGROINFO GALUH, 2(2), 117. https://doi.org/10.25157/jimag.V2i2.67

Higuchi, A, Moritaka, M., \& Fukuda, S. (2012). The Impact of Socio-Economic Characteristics on Coffee Farmers' Marketing Channel Choice: Evidence from Villa Rica, Peru. Sustainable Agriculture Research, 1(1), p13. https://doi.org/10.5539/sar.v1n1p13

Jakiyah, U., \& Sukmaya, S. G. (2020). Efisiensi Pemasaran Komoditas Manggis Di Kabupetan Tasikmalaya. Mimbar Agribisnis: Jurnal Pemikiran Masyarakat Ilmiah Berwawasan Agribisnis, 6(1), 201. https://doi.org/10.25157/ma.v6i1.2964

Kai, Y., Baruwadi, M., \& Tolinggi, W. K. (2016). Analisis Distribusi Dan Margin Pemasaran Usahatani Kacang Tanah Di Kecamatan Pulubala Kabupaten Gorontalo. http://ejurnal.ung.ac.id/index.php/AGR/article/view/1409/1109

Khaswarina, S., Kusumawaty, Y., \& Eliza, E. (2019). Analisis Saluran Pemasaran dan Marjin Pemasaran Bahan Olahan KaretRakyat (Bokar) di Kabupaten Kampar. Unri Conference Series: Agriculture and Food Security, 1, 88-97. https://doi.org/10.31258/unricsagr.1a12

Maharani, H., \& Furyanah, A. (2020). Analisis Saluran Pemasaran Kopi Robusta Di Desa Cilumping Kecamatan Dayeuhluhur Kabupaten Cilacap Provinsi Jawa Tengah. 9.

Murtiningrum, F., \& Gabrienda, G. (2019). Analysis of the Marketing Channels of Coffee. Journal of Agri SocioEconomics and Business, 1(2), 15-28. https://doi.org/10.31186/jaseb.1.2.15-28 
Pratiwi, A. M., Kaskoyo, H., Herwanti, S., \& Qurniati, R. (2019). Saluran Pemasaran Kopi Robusta (Coffea Robusta) Di Agroforestri Pekon Air Kubang, Kecamatan Air Naningan, Kabupaten Tanggamus. Jurnal Belantara, 2(2), 76. https://doi.org/10.29303/jbl.V2i2.183

Puspasari, E. D., Asmara, R., \& Riana, F. D. (2017). Analisis Efisiensi Pemasaran Bunga Mawar Potong (Studi Kasus di Desa Gunungsari, Kecamatan Bumiaji, Kota Batu). Jurnal Ekonomi Pertanian dan Agribisnis, 1(2), 80-93. https://doi.org/10.21776/ub.jepa.2017.001.02.2

Putri, R. K., Nurmalina, R., \& Burhanuddin, B. (2018). Analisis Efisiensi Dan Faktor Yang Memengaruhi Pilihan Saluran Pemasaran. MIX: JURNAL ILMIAH MANAJEMEN, 8(1), 109. https://doi.org/10.22441/mix.2018.v8i1.007

Sari, M. Y. (2019). Isolasi Asam Klorogenat Dari Ekstrak Air Biji Kopi Robusta (Coffea Canephora).

Septiyani, D., Triarso, I., \& Kurohman, F. (2017). Analisis Distribusi Dan Margin Pemasaran Hasil Tangkapan Cumi-Cumi (Loligo Sp) Di Kabupaten Kendal, Jawa Tengah. 10.

Situmorang, T. S., Alamsyah, Z., \& Naenggolan, S. (2015). Analisis Efisiensi Pemasaran Sawi Manis Dengan Pendekatan Structure, Conduct, And Performance(SCP) Di Kecamatan Jambi Selatan Kota Jambi. Jurnal IImiah Sosio-Ekonomika Bisnis, 18(2). https://doi.org/10.22437/jiseb.v18i2.2830

Soetrisno, L. (2002). Paradigma baru pembangunan pertanian: Sebuah tinjauan sosiologis. Penerbit Kanisius.

Sofanudin, A, \& Budiman, E. W. (2017). Analisis Saluran Pemasaran Cabai Rawit (Capsicum Frutescens. L) (Studi kasus di Kecamatan Kanigoro, Kabupaten Blitar. https://doi.org/10.35457/viabel.v11i1.234

Wowiling, C. C., Pangemanan, L. R. J., \& Dumais, J. N. K. (2019). Analisis Pemasaran Jagung Di Desa Dimembe Kecamatan Dimembe Kabupaten Minahasa Utara. AGRI-SOSIOEKONOMI, 14(3), 305. https://doi.org/10.35791/agrsosek.14.3.2018.22326 